\title{
The invasive appearance of Eudiaptomus gracilis (G.O. Sars 1863) in Lago Maggiore
}

\author{
Anna VISCONTI and Marina MANCA* \\ CNR Institute of Ecosystem Study, Largo V. Tonolli 50, 28922 Verbania Pallanza, Italy \\ *e-mail corresponding author:m.manca@ise.cnr.it
}

\begin{abstract}
Large, deep, subalpine Lago Maggiore has been regarded as an example of stability and resilience: while changes in zooplankton taxa composition were mainly recorded with introduction of allochthonous fish in the 1950s, eutrophication and reoligotrophication mainly affected abundance and biomass. As part of a monitoring project on pelagic zooplankton, samples were routinely collected in the open-water at least monthly over a 30 year period. During this time, copepods' numerical dominance resulted from the same species assemblage, including large Mixodiaptomus laciniatus (W. Lilljeborg 1889) and Cyclops abyssorum (G. O. Sars 1863), and smaller Eudiaptomus padanus (G. Burckhardt 1900) and Mesocyclops leuckarti (C. Claus 1857); large Megacyclops viridis (L. Jurine 1820) were recorded only occasionally in the open-water. Eudiaptomus gracilis (G.O. Sars 1863) invaded the lake in October 2006. Adult body length was typical of oligotrophic freshwater environments, and largely overlapped that of M. laciniatus, a species rarer than con-generic and numerically-dominant $\mathrm{E}$. padanus. In the two years following E. gracilis invasion, M. laciniatus was not found in Lago Maggiore, suggesting that it disappeared from the lake. This is the second important change in Lago Maggiore copepod community, following the disappearance of Heterocope saliens (W. Lilljeborg 1863), which was recorded in the 1950s attendant with the introduction of fishes to the lake. The replacement of M. laciniatus by E. gracilis in Lago Maggiore is regarded as an opportunity for discussing the importance of size-mediated, rather than taxonomic-based, interactions between invasive and indigenous species, given the species' overlapping body size and similar level of abundance.
\end{abstract}

Key words: invasion, body size, zooplankton, copepods

\section{INTRODUCTION}

Large and deep, subalpine Lago Maggiore has been regarded as an example of stability and resilience (de Bernardi et al. 1990): eutrophication and reoligotrophication affected zooplankton abundance and biomass, while significant changes in community structure were only recorded with the successful introduction of allochthonous fish during the fifties (Manca et al. 1992). The latter included the disappearance of two non-rare zooplankton species from the open water: the predatory calanoid copepod Heterocope saliens, later on able to persist only in few high mountain lakes in Lago Maggiore's drainage basin, and the large cladoceran Sida crystallina (O.F. Müller 1776) var. limnetica, a truly pelagic variant of the species, characterized by the atrophy of the nuchal gland. Apart from these changes, over a period of $\sim 30$ years, numerical dominance of copepods in the zooplankton was basically a result of a same species assemblage, composed by two calanoids, the large Mixodiaptomus laciniatus and the small Eudiaptomus padanus padanus, and three cyclopoids, the large Cyclops abyssorum, and the small Mesocyclops leuckarti. The largest species, Megacyclops viridis, was mainly restricted to deep waters, being only occasionally collected at the adult stage in the openwater zooplankton.
Despite the barrier of the Alps, chances for species invasion into Lago Maggiore's drainage basin does not seem to be remote, as it is located in the Po River Plain, the most populated and developed area of Italy (MacIsaac et al. 2001). An example of species immigration may be found in the successful and relatively fast re-colonization of nearby Lake Orta after its chemical restoration (Bonacina 2001). Despite being connected to Lake Lugano, which is also included in its drainage basin, through the River Tresa, Lago Maggiore was not affected by the invasion of Eudiaptomus gracilis. This species successfully invaded Lake Lugano during its eutrophication phase, and out-competed indigenous, congeneric Eudiaptomus padanus. Local biotic and abiotic factors did not allow for successful immigration which may have occurred during eutrophication and reoligotrophication of Lago Maggiore (biotic resistance as a reason for resilience). In such a system, the recent finding of Eudiaptomus gracilis (G.O. Sars 1863) in the open-water zooplankton is worthy of analysis (Manca et al. 2007). This copepod is interesting both because it affects other copepods, the most stable component of the zooplankton community during changes in trophy (Manca et al. 1992), and because it provides an opportunity to test the relative importance of sizemediated rather than taxonomic-based, interactions between invasive and indigenous taxa (Ricciardi \& Mottiar 2006). 


\section{STUDY SITE}

Studies on zooplankton of Lago Maggiore, the second deepest and largest subalpine lake in Italy, date back to 1874. A regular limnological monitoring was started in 1978 by CNR-ISE on behalf of the SwissItalian Commission for the protection of Lago Maggiore waters, when the effects of eutrophication became evident. Oligotrophic by its nature (Guilizzoni et al. 1983), the lake reached a quasi-eutrophic state in middle 1970 s, as a consequence of the post-war economic development. Phosphorus load continued to increase until 1979, when the mean in-lake TP concentration (men value in the water column at winter overturn) reached $c a 40 \mu \mathrm{g} \mathrm{L}^{-1}$, corresponding to $c a 30 \mu \mathrm{g} \mathrm{L}{ }^{-1} \mathrm{RP}$. Mean epilimnetic (upper $20 \mathrm{~m}$ ) chlorophyll- $a$ concentration increased and primary productivity rose from 0.3 $\mathrm{g} \mathrm{C} \mathrm{m}^{-2} \mathrm{~d}^{-1}$ to $0.75 \mathrm{~g} \mathrm{C} \mathrm{m}^{-2} \mathrm{~d}^{-1}$. Following the introduction of sewage treatment plants and a reduction of phosphorus in detergents, the lake went through a reoligotrophication, with a gradual decrease in phosphorus concentration since the early 1980s (Manca et al. 1992). A decrease in phytoplankton algal biomass and primary production, and changes in planktonic communities were detected only by the end of the 1980 s, after phosphorus concentration fell down to $15 \mu \mathrm{g} \mathrm{L}^{-1}$ (in 1988: Manca \& Ruggiu 1998). Changes in trophy undoubtedly affected the biota; however, as also suggested by a high resolution study on subfossil Cladocera, the impact of fish introduction in the middle 1940s was probably much stronger for species richness and diversity, as taxa lost with these manipulations were never replaced (Manca et al. 2007).

\section{METHODS}

Zooplankton samples were collected with a ClarkeBumpus plankton sampler (76 $\mu \mathrm{m}$ nylon net) in the upper $50 \mathrm{~m}$ depth from a boat moving at a low, constant cruise speed $\left(0.6 \mathrm{~m} \mathrm{~s}^{-1}\right)$, allowing for the filtration of at least $1000 \mathrm{~L}$ of lake water along a sinusoidal sampling trajectory. The resulting samples were both integrated horizontally and vertically, thus avoiding problems related to the occurrence of plankton swarms and of a non-uniform distribution of zooplankton along the water column.

Samples were collected monthly, at a station corresponding to the maximum depth of the lake $(370 \mathrm{~m})$, which is used for the monitoring of Lago Maggiore pelagic environment. The samples were preserved in pure ethanol and counted with a distinction of species and developmental stages, on at least $10 \%$ of the total volume (Manca et al. 1992). Clutch size was also recorded, and the body length of adults (furca excluded) determined by measuring at least 25 individuals or, when fewer, the total number of individuals/sample. Additional samples were collected from Lago Maggiore littoral and from River Tresa, which connects Lago Maggiore with Lake Lugano, as well as from Bardello and Acquanegra Springs, through which Lago Maggiore is connected with Lake Varese.

\section{RESULTS}

Eudiaptomus gracilis was first detected in the openwater zooplankton of Lago Maggiore in October 2006 (Fig. 1), after a sharp decline in abundance of indigenous copepods. The latter is regularly recorded in late summer, when infestation from epizoonts and ellobiopsids is most intense (Manca et al. 2004). Eudiaptomus gracilis abundance slightly increased in December, although remaining at far lower levels than the con-generic E. padanus. The latter did not seem to be affected by the appearance of the new species, remaining the dominant copepod in the lake, with population densities seven times higher than those of the other two species.

The success of the invader was concomitant with a disappearance of Mixodiaptomus laciniatus, a calanoid copepod reported since the earliest studies on Lago Maggiore's zooplankton, which date back to the second half of the XIX Century (Pirocchi 1947). Although present at a level of abundance an order-of-magnitude lower than the smaller-bodied E. padanus, this large calanoid was a permanent component of Lago Maggiore's open water zooplankton community, over the years contributing significantly to total copepod biomass (de Bernardi et al. 1990).

In Lago Maggiore, the body length of M. laciniatus adults averaged $1.35 \mathrm{~mm}$, with females and ovigerous females generally $\sim 1.4 \mathrm{~mm}$ and males $c a 1.3 \mathrm{~mm}$ in body length (Fig. 1 and Manca et al. 2007). Eudiaptomus gracilis males and females averaged $1.4 \mathrm{~mm}$ and $1.55 \mathrm{~mm}$, respectively, a body length very close to that reported by Einsle (1993) as typical for adults of the species. A similar body size was also measured for individuals collected in the littoral of Lago Maggiore, in River Tresa and in Bardello and Acquaviva springs. Body size of the invader appeared closer to the larger and rarer M. laciniatus, than to congeneric and dominant E. padanus (Fig. 1). During spring and autumn 2006, the body length of adult E. padanus slightly increased, with males of $1.1 \mathrm{~mm}$, and females and ovigerous females reaching a maximum value of $1.2 \mathrm{~mm}$, as has been generally observed in the long-term (Manca \& de Bernardi 2002). The increase in the first two months of 2007 (Fig. 1) was mainly due to females and ovigerous females (with an average body length of $1.25 \mathrm{~mm}$ ).

In addition to body size, clutch size (data not shown) also was highest in the invasive species, with values ranging between 15 and 10 eggs clutch $^{-1}$ in December 2006 and February 2007, respectively. During the same period, clutch size of $E$. padanus was lower over all seasons, varying between 3 and 9 eggs clutch $^{-1}$ [in winter and spring, respectively, i.e. when the population usually reaches the two reproductive maxima (Stella 1982)]. A very few egg clutches of M. laciniatus found in 2006 and early 2007 samples resulted on an average of 


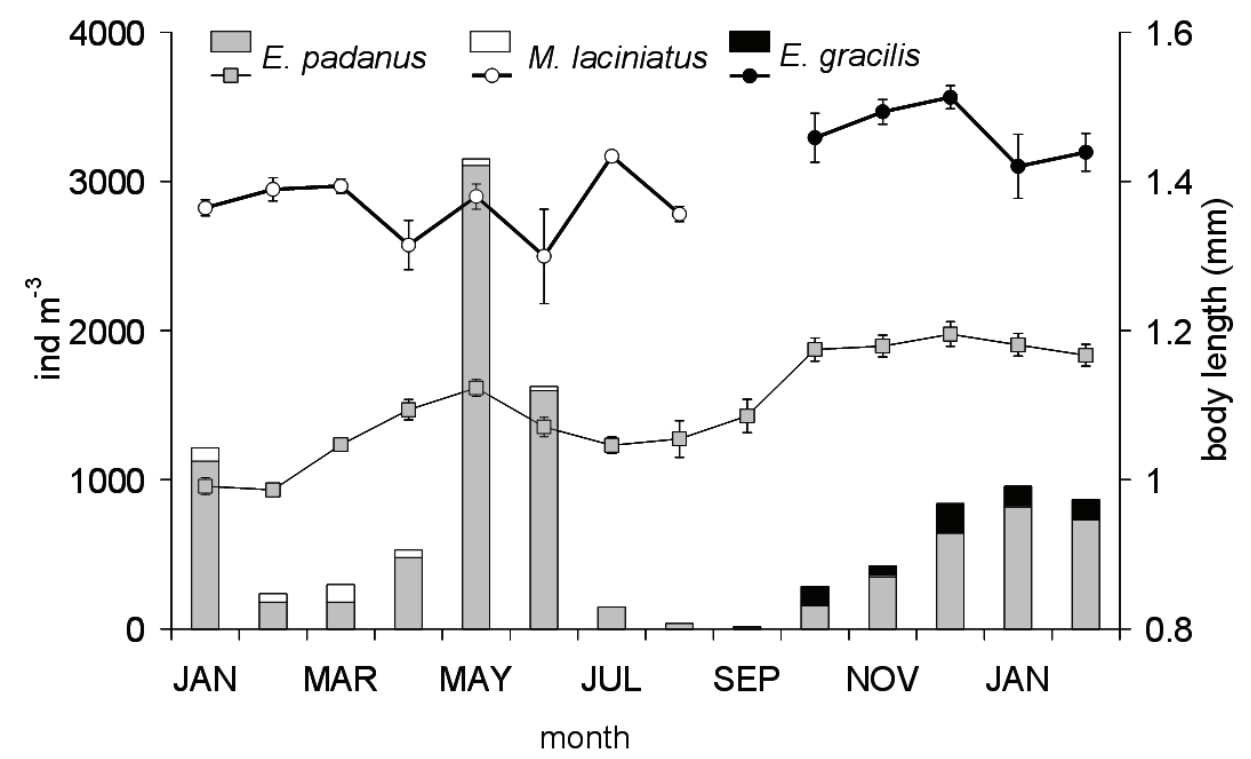

Fig.1. Population density and body length (mean \pm SE) of M. laciniatus, E. padanus and E. gracilis adults in Lago Maggiore in 2006 and early 2007 , before and soon after the invasion of the latter.

a size comparable to that of E. padanus (6 eggs clutch $\left.^{-1}\right)$. In the long-term, however, clutches of the former were generally larger (Manca \& de Bernardi 1992), fully comparable with those presently recorded for the invader.

\section{DISCUSSION AND CONCLUSIONS}

Data on Lago Maggiore zooplankton for the period 2007-2009 confirmed that E. gracilis replaced $M$. laciniatus at comparable levels of abundance (Manca et al. 2007, 2009), leading to the disappearance of the latter.

The invasion of Lago Maggiore in 2006 was recorded 26 years later than the first detection of $E$. gracilis in Lake Sirio, a small peri-alpine lake located in the westernmost area of the Piedmont Region (de Bernardi et al. 1984, in Riccardi \& Rossetti 2007). Over this time period, the species spread $230 \mathrm{~km}$ East in the Po River Plain, and $100 \mathrm{~km}$ North, in the subalpine region. Lake Lugano was the second invaded site and, despite the closeness and a connection through the River Tresa, E. gracilis was not able to establish in Lago Maggiore until 2006. We calculated a rate of spread of E. gracilis in Northern Italy of ca $0.1 \log \mathrm{km} \mathrm{y}^{-1}$, a value which is low with respect to those of rapidly dispersing invasive species, that are able to spread at three-orderof-magnitude higher rates (Ricciardi \& Cohen 2007). Owing to these data, invasiveness of E. gracilis in Italy may, thus far, be classified as low. The successful colonization of Italian lakes, however, occurred concomitant with important changes in zooplankton community structure, as in four of the invaded sites E. gracilis fully replaced the con-generic $E$. padanus, the most widely distributed species in Italian natural lakes. Such a result is not surprising, as invasiveness is not directly correlated with impact (Ricciardi \& Cohen 2007).
The replacement of a native species by a con-generic one allows for discussing Darwin's naturalization hypothesis (Darwin 1859; in Ricciardi \& Mottiar 2006), according to which species of the same genus would be less likely able to establish because of a close similarity in "habits, constitution and structure". Such a similarity would result in a large niche overlap and a stronger competition with congeneric than with noncongeneric ones. On the other hand, however, Darwin himself also stressed that congeneric species might be favored in successfully invading sites occupied by species of the same genus, with which they share adaptation traits to the environment ("pre-adaption hypothesis"; Darwin ibidem). Notably, in some cases, invasions succeeded when a native congeneric taxon was already decreasing in density (e.g., Ravera 1981), a fact which might be regarded as a temporary condition of advantage for the invader. A similar mechanism was suggested for success of Daphnia hybrids (Hoekstra \& Spaak 1995).

While initially the substitution of E. padanus by $E$. gracilis in Italian lakes was mainly attributed to eutrophication [e.g., in Lake Lugano (Ravera 1981)], later establishments of permanent populations of the invader in Italian lakes, in some cases coupled with a replacement of the indigenous E. padanus, did not confirm a prominent role of trophic conditions in this respect.

The replacement by E. gracilis of a congeneric taxon was generally matched with a similar body size, and $E$. gracilis often smaller than reported in the literature [e.g., in Lake Candia (Riccardi \& Giussani 2007)]. On average, body size of individuals measured in Lago Maggiore littoral and open-water, as well as in River Tresa and in the two springs from which it was collected resulted those typical of the species (Fig. 1 and Einsle 1963), i.e. close to those of M. laciniatus. The latter is a 
relatively rare taxon, distributed in water-bodies of Northern and Western Europe, and in Morocco. In Italy, it was abundant in the deep and large lakes Maggiore and Lugano. After disappearing from the latter during eutrophication in the early 1980s (Ravera 1981), Lago Maggiore was the only large lake in which it was able to persist with a permanent population, although at low levels of abundance.

If confirmed by further studies, the disappearance of M. laciniatus will be the second calanoid taxa lost from Lago Maggiore, following the extirpation of the large predator Heterocope saliens in the 1950s. The latter is a glacial relict, whose presence in Lago Maggiore, as to a minor extent can be considered that of $M$. laciniatus, could be related to a large contribution of a number of Alpine lakes $(>300)$ and the relatively high elevation (mean $1272 \mathrm{~m}$ a.s.1.) of the drainage basin.

In Lago Maggiore, a shift in breeding and growth periods and the uni-/multi-voltine nature of M. laciniatus and E. padanus populations, respectively, allowed for the coexistence of the species. Moreover, differences in feeding behaviour resulting from a different body size may also be relevant in this respect, suggesting that body size more than taxonomical attribution is important for ecological role (e.g., Hutchinson 1967) and the outcome of invasions (Ricciardi \& Mottiar 2006).

Eudiaptomus padanus is still the most abundant calanoid copepod in Lago Maggiore, with reproductive maxima in spring and autumn. Eudiaptomus gracilis seems to have replaced $M$. laciniatus for both abundance and the univoltine nature of its population (Manca et al. 2009). The large overlap in body size of the invader with respect to the indigenous taxon may be the reason for the peculiar pattern observed in Lago Maggiore. Although in most studies phylogenetic relationships are used to predict the success of an invader and the replacement of indigenous taxa, taxonomic similarity might not well correlate with ecological similarity, thus explaining why in some cases the preadaptation hypothesis is not supported by experimental evidence (Ricciardi \& Mottiar 2006).

Some invasions require multiple introductions to establish reproducing populations of invaders (Lockwood et al. 2005); further data are needed to investigate the success of E. gracilis in Lago Maggiore, as well as the impact in terms of functional diversity (intended as ecological diversity). A two-year evidence of a substitution of the rare, indigenous $M$. laciniatus, of which Lago Maggiore was one of the last refugia in Italy, is far from being negligible, not least when a large proportion of species seems to be required for conserving functional diversity (Petchey \& Gaston 2002).

The large inter-annual variability in zooplankton population density observed in recent years (Manca et al. 2007) may be regarded as a condition for temporary instability and ecosystem heterogeneity, which might favor the success of non-indigenous taxa and their replacement of indigenous ones. Further research, focused on functional redundancy (i.e., species similarity in ecological strategy and resource use) will allow for estimating the impact of the observed invasion and the replacement of an indigenous species on ecosystem stability.

\section{ACKNOWLEDGMENTS}

We are very grateful to $\mathrm{H}$. MacIsaac, N. Riccardi and G. Giussani for critical comments and the revision of the manuscript.

\section{REFERENCES}

Bonacina, C. 2001. Lake Orta: the undermining of an ecosystem. J. Limnol., 60: 53-59.

Darwin, C. 1859. On the origin of species by means of natural selection. John Murray London: $490 \mathrm{pp}$.

de Bernardi, R., G. Giussani, R. Mosello \& I. Origgi. 1984. Quadro limnologico di cinque piccoli laghi piemontesi (Avigliana, Trana, Candia, Viverone e Sirio). Documenta Ist. ital. Idrobiol., 5: $97 \mathrm{pp.}$

de Bernardi, R., G. Giussani, M. Manca \& D. Ruggiu. 1990. Trophic status and the pelagic system in Lago Maggiore. Hydrobiologia, 191: 1-8.

Einsle, U. 1993. Crustacea: Copepoda: Calanoida und Cyclopoida. Süßwasserfauna von Mitteleuropa 8/4-1U. Gustav Fischer Verlag, Stuttgart: 209 pp.

Guilizzoni, P., G. Bonomi, G. Galanti \& D. Ruggiu. 1983. Relationship between sedimentary pigments and primary production: evidence from core analysis of twelve Italian lakes. Hydrobiologia, 103: 103-106.

Hutchinson, G.E. 1967. A Treatise on Limnology. Vol. II. John Wiley and Sons, Inc., New York: 1115 pp.

Lockwood, J.L., P. Cassey \& T. Blackburn. 2005. The role of propagule pressure in explaining species invasions. Trends in Ecology and Evolution, 20: 223-228.

MacIsaac, H.J., I.A. Grigorovich \& A. Ricciardi. 2001. Reassessment of species invasions concepts: the Great Lakes basin as a model. Biol. Invasions, 3: 405-416.

Manca, M. \& R. de Bernardi. 1992 Indagini sullo zooplancton. In: CNR Istituto per lo Studio degli Ecosistemi (Ed.), Ricerche sull'evoluzione del Lago Maggiore. Aspetti Limnologici. Programma quinquennale 1983-1987 (Campagna 1992) e rapporto quinquennale 1988-1992. Commissione Internazionale per la protezione delle acque Italo-Svizzere: 68-78.

Manca, M., A. Calderoni \& R. Mosello. 1992. Limnological research in Lago Maggiore: studies on hydrochemistry and plankton. Mem. Ist. ital. Idrobiol., 50: 171-200.

Manca, M. \& D. Ruggiu. 1998. Consequences of pelagic food web changes during a long-term lake oligotrophication process. Limnol. Oceanogr., 43: 1368-1373.

Manca, M., A. Carnovale \& P. Alemani. 2004. Exotopic protrusions and ellobiopsids' infections on zooplanktonic copepods of a large, deep, subalpine lake, Lago Maggiore (Northern Italy). J. Plankton Res., 26: 1-8.

Manca, M., A. Visconti \& R. de Bernardi. 2007. Indagini sullo zooplancton In: CNR Istituto per lo Studio degli Ecosistemi (Ed.), Ricerche sull'evoluzione del Lago Maggiore. Aspetti limnologici. Programma quinquennale 2003-2007. Campagna 2007 e Rapporto quinquennale 2003-2007. Commissione Internazionale per la protezione delle acque italo-svizzere: $60-66$.

Manca, M., A. Visconti \& A. Fadda. 2009. Popolamento zooplanctonico nelle tre stazioni nei quattro periodi dell'anno. In: CNR Istituto per lo Studio degli Ecosistemi (Ed.), Ricerche sull'evoluzione del Lago Maggiore. Aspetti limno- 
logici. Programma quinquennale 2008-2012. Campagna 2008. Commissione Internazionale per la protezione delle acque italo-svizzere: $47-52$.

Petchey, O.L. \& K.J. Gaston 2002. Extinction and the loss of functional diversity. Proc. R. Soc. Lond B, 269: 17211727.

Pirocchi, L. 1947. Struttura e vicende delle biocenosi mesoplanctiche del Lago Maggiore. Mem. Ist. ital. Idrobiol., 3: 58-119.

Ravera, O. 1981. The influence of nutrient enrichment on freshwater zooplankton. In: Restoration of lakes and inland waters. Int. Symp. Inland waters and lake Restoration. Portland. Sept. 8-12/80. EPA 440/5-81-010: 210-217.

Riccardi, N. \& G. Giussani. 2007. The relevance of life history traits in the establishment of the invader Eudiaptomus gracilis and the extinction of Eudiaptomus padanus in Lake Candia (Northern Italy): evidence for competitive exclusion? Aquatic Ecology, 241: 243-254.

Ricciardi, A. \& M. Mottiar 2006. Does Darwin's naturalization hypothesis explain fish invasions? Biol. Invasions, 8: 1403-1407.

Ricciardi, A. \& J. Cohen. 2007. The invasiveness of an introduced species does not predict its impact. Biol. Invasions, 9: 309-315.

Spaak, P. \& J.R. Hoekstra. 1995. Life history variation and the coexistence of a Daphnia hybrid with its parental species. Ecology, 76: 553-564.

Stella, E. 1984. Crustacea - Copepoda: Calanoida d'acqua dolce. Calderini, Bologna: $101 \mathrm{pp}$.

Received: March 2010

Accepted: May 2010 